\title{
PENGEMBANGAN PERPUSTAKAAN PERGURUAN TINGGI YANG BERORIENTASI PADA CIVITAS AKADEMIKA DAN PERKEMBANGAN TEKNOLOGI INFORMASI
}

\author{
Elok Inajati *), RM Endhar Priyo Utomo**) \\ Fakultas Ekonomika dan Bisnis Universitas Diponegoro, Semarang, Indonesia \\ email: elok.inayati68@gmail.com*), endhar@undip.ac.id**)
}

Naskah diterima: 4 Mei; direvisi: 11 Mei; disetujui: 21 Mei 2019

\begin{abstract}
Abstrak
Kompetensi pustakawan sebagai pengelola perpustakaan dan perkembangan teknologi informasi, memiliki pengaruh dalam pengembangan perpustakaan perguruan tinggi. Adanya perkembangan teknologi informasi saat ini berpengaruh terhadap semakin tingginya tuntutan pemustaka untuk bisa mendapatkan layanan perpustakaan yang semakin berkualitas. Hal lain yang diperlukan agar sebuah perpustakaan perguruan tinggi bisa memberikan layanan yang berkualitas adalah dengan tersedianya pustakawan yang memiliki kompetensi yang baik dalam mengelola sebuah perpustakaan. Adanya perpustakaan yang bisa memberikan layanan yang berkualitas akan bisa meningkatkan kepuasan pemustaka dalam menggunakan layanan di perpustakaan.
\end{abstract}

Kata kunci: Pengembangan perpustakaan, Kualitas layanan, Perpustakaan perguruan tinggi

\begin{abstract}
Librarian competence as a library manager and the development of information technology influences the development of higher education libraries. The current development of information technology influences the increasingly high demands of users to be able to get increasingly high-quality library services. Another thing that is required so that a university library can provide quality services is the availability of librarians who have good competence in managing a library. The existence of a library that can provide quality services will be able to increase the satisfaction of users in using services in the library.
\end{abstract}

Keyword: library development, quality of service, academic library

\section{PENDAHULUAN}

Perpustakaan merupakan salah satu unit pelaksana teknis di perguruan tinggi dengan tugas pokoknya sebagai pengelola informasi ilmiah secara efektif dan efisien untuk menunjang pelaksanaan Tri Dharma Perguruan Tinggi. Fungsi perpustakaan sebagai sumber informasi ilmiah di Perguruan Tinggi. Pasal 40 Peraturan Pemerintah tentang Pendidikan Tinggi menegaskan bahwa perpustakaan merupakan unsur penunjang pendidikan tinggi. Secara harafiah, unsur penunjang dapat diartikan sebagai sesuatu yang harus ada untuk kesempurnaan yang ditunjang. Peran strategis ini juga terlihat jelas dalam proses akreditasi sebuah perguruan tinggi, dimana perpustakaan merupakan unsur utama, walau bukan yang pertama.

Secara teori, perpustakaan sebetulnya memiliki peran strategis dalam eksistensi pendidikan tinggi. Sebagai unsur penunjang penting, perpustakaan tidak dapat diabaikan, khususnya dalam hal pencapaian visi. Jika sebuah universitas ingin menjadi 'universitas bertaraf internasional', otomatis perpustakaan 
juga harus ikut menjadi 'perpustakaan bertaraf internasional'. Hal ini berkaitan dengan bagaimana cara mengelola sumber daya perpustakaan sehingga memenuhi kebutuhan dasar perguruan tinggi. Selanjutnya mengembangkan sistem informasi ilmiahnya dengan dukungan teknologi informasi sehingga dapat dinikmati oleh seluruh sivitas akademinya dengan efektif dan efisien. Jika indikator akuntabilitasnya baik maka pasar atau user akan merespon positif dan membuat posisi perpustakaan sebagai penyedia jasa yang capable atau dapat dipercaya sekaligus dapat diperkirakan mutunya akan tetap kuat posisinya di pasar penyedia jasa informasi. Sebaliknya jika pasar atau pengguna merespon negatif maka perpustakaan harus segera berbenah diri dengan melakukan evaluasi terhadap indikator-indikator dari akuntabilitas sebuah perpustakaan yang bertanggungjawab kepada publiknya.

Dilain pihak, teknologi informasi dan komunikasi telah berkembang dengan pesatnya. Banyak teknologi informasi dan komunikasi ditawarkan kepada masyarakat, perusahaan pemasok dalam bidangnya saling berlomba untuk menawarkan hasil teknologinya. Produk-produk teknologi mereka yang terbaru meliputi android, wi-fi, jaringan HSDPA, touchscreen entry-level, symbian, MacBook Pro-calibre CPU, OLED touchscreen, Digital Book, HP Touchsmart, mobile dual-core Intel Atom N550, GSM dual on, dan lain sebagainya.

Jaringan internet, intranet, dan Local Area Network menjadi sarana penting dalam menunjang bisnis, perkantoran, pendidikan dan lain sebagainya. Adanya perkembangan teknologi informasi dan komunikasi saat ini menyebabkan kemudahan-kemudahan dalam mencari informasi dan berkomunikasi. Pada umumnya orang menyebut telah terjadi peledakan informasi atau yang disebut era globalisasi informasi. Era globalisasi informasi mempengaruhi perilaku masyarakat dalam mengelola dan memanfaatkan informasi serta berkomunikasi. Perilaku masyarakat dalam mencari informasi tidak hanya di perpustakaan saja, tetapi juga di internet. Bahkan informasi yang tidak ada di perpustakaan dapat mereka cari di internet. Pengunjung perpustakaan mulai berkurang. Fenomena seperti itu perlu untuk segera dijawab dengan mengembangkan perpustakaan perguruan tinggi yang berorientasi kepada civitas akademika dan perkembangan teknologi informasi.

\section{PEMBAHASAN}

Dalam mengembangkan perpustakaan perguruan tinggi memerlukan suatu tahaptahap pengembangan, yaitu : (1). Menentukan arah pengembangan, (2). Standarisasi sumber daya, (3). Pembangunan sistem informasi, dan (4). Evaluasi.

\section{Menentukan Arah Pengembangan}

Sebelum dilakukan pengembangan perlu adanya arah perencanaan pengembangan masa depan perpustakaan dalam bentuk visi, misi, tujuan, sasaran, dan program kerja. Visi adalah pernyataan yang berorientasi ke masa depan tentang apa yang diharapkan perpustakaan.

Misi adalah deskripsi mengenai tugas, kewajiban, dan rencana tindakan yang dirumuskan sesuai dengan visi perpustakaan yang harus digunakan dalam menunjang pelaksanaan Tri Dharma Perguruan Tinggi. Tujuan adalah rumusan kompetensi perpustakaan yang sesuai dengan kebutuhan dan standar yang dituntut oleh civitas akademika.

Sasaran adalah target yang terukur sebagai indikator tingkat keberhasilan dari tujuan yang telah ditetapkan. Sedangkan program kerja adalah tindakan perpustakaan untuk mencapai tujuan dan sasaran perpustakaan. Untuk mencapai hal itu, direalisasikan dalam rencana kegiatan tahunan (RKT). RKT merencanakan peningkatan kualitas sumber daya manusia, sumber daya bahan, sumber daya sistem, sumber daya alat, dan sumber daya lingkungan. Dalam RKT ada indikator kinerja dan target yang harus dicapai. Indikator kinerja yaitu peningkatan jumlah pengunjung, peminjam, buku yang dipinjam, dan akses informasi. Target adalah jumlah minimal rata-rata indikator kinerja. Target mengacu hasil kinerja tahun yang lalu. Capaian target diatas hasil kinerja tahun yang lalu sehingga ada peningkatan. 
Visi dan misi perpustakaan mengacu pada visi dan misi perguruan tingginya. Visi dan misi perpustakaan tercantum di dalam rencana strategis (renstra) perpustakaan.

Analisis kelemahan dan kekuatan perpustakaan merupakan suatu cara untuk membuat renstra. Kelemahan dan kekuatan perpustakaan merupakan bahan untuk menyusun renstra. Untuk mengetahui kelemahan dan kekuatan perpustakaan dilakukan dengan analisis SWOT. Analisis SWOT merupakan analisis untuk memperoleh kesimpulan keadaan (posisi) organisasi agar dapat menentukan visi, misi, tujuan, dan program organisasi. Inti dari analisis SWOT yaitu

a. Menganalisis keadaan internal perpustakaan dengan menjabarkan faktor-faktor Strengths (kekuatan) dan Weakness (kelemahan).

b. Menganalisis keadaan eksternal perpustakaan dengan menjabarkan faktor-faktor Opportunitics (peluang) dan Threats (ancaman).

Penjabaran faktor-faktor internal dan eksternal perpustakaan berdasarkan penyebaran kuesioner yang diisi oleh sivitas akademika. Jadi analisis SWOT perpustakaan berdasarkan orientasi sivitas akademik.

\section{Standarisasi Sumber daya Perpustakaan}

Untuk bisa melaksanakan dan memiliki kemampuan mengoperasionalkan layanan perpustakaan baik tradisional maupun modern sesuai dengan perkembangan dan tuntutan perkembangan jaman, dengan kata lain perkembangan TIK dan salah satunya Perpustakaan Digital, tentu saja diperlukan standarisasi perpustakaan. Untuk itulah dalam Undang-Undang Perpustakaan juga diatur lebih lanjut tentang standar-standar yang diperlukan dalam kerangka pengembangan perpustakaan.

Standar perpustakaan diharapkan dan dimaksudkan sebagai acuan penyelenggaraan, pengelolaan dan pengembangan perpustakaan. Pengaturan standar secara nasional dilakukan dalam rangka membangun sistem masyarakat yang mampu mendorong meningkatkan dan menjamin mutu barang dan atau / jasa serta mampu memfasilitasi agar diterimanya produk nasional dalam kawasan pasar global. Dengan demikian sistem tersebut diharapkan dapat meningkatkan daya saing bangsa dipasar global atau internasional.

Standar Nasional Perpustakaan berfungsi sebagai acuan penyelenggaraan, pengelolaan dan pengembangan perpustakaan. Standar Nasional Perpustakaan bertujuan menjamin mutu perpustakaan dalam rangka memberikan pelayanan kepada pemustaka, meningkatkan kegemaran membaca serta memperluas wawasan dan pengetahuan untuk mencerdaskan kehidupan bangsa.

Adapun lingkup Standar Nasional Perpustakaan yang dikehendaki dalam Undang-Undang meliputi 6 standar, sebagai berikut :

a. Standar koleksi perpustakaan.

b. Standar sarana dan prasarana perpustakaan

c. Standar pelayanan perpustakaan.

d. Standar tenaga perpustakaan

e. Standar penyelenggaraan perpustakaan, dan

f. Standar pengelolaan.

Beban kerja dan kegiatan kepustakaan dan kepustakawanan yang diwadahi dalam wujud organisasi kelembagaan perpustakaan, sebagaimana diakui dalam Undang-Undang bahwa yang dimaksud Perpustakaan adalah institusi pengelola koleksi karya tulis, karya cetak dan / atau karya rekam secara profesional dengan sistem baku guna memenuhi kebutuhan pendidikan, penelitian, pelestarian, informasi dan rekreasi para pemustaka.

Artinya bahwa perpustakaan sebagai lembaga profesional dengan sistem baku, tetapi ternyata apresiasi dan kenyataan di lapangan belum sebaik yang diinginkan. Demikian juga tatkala lembaga perpustakaan sebagai lembaga profesional, artinya juga harus diurus oleh orang-orang yang profesional, bukan pegawai-pegawai unskill (tidak terpakai apalagi pegawai buangan) ditempatkan di perpustakaan. Dikehendaki dalam UndangUndang, bahwa Pusakawan adalah seseorang yang memiliki kompetensi yang diperoleh melalui pendidikan dan /atau pelatihan kepustakawanan serta mempunyai tugas dan 
tanggung jawab untuk melaksanakan pengelolaan dan pelayanan perpustakaan. Artinya bahwa seorang pustakawan meiliki kompetensi seorang akademisi dan pada saatnya nanti juga disertifikasi.

Permasalahan umum pada era otonomi, era demokratisasi belum lagi tuntutan dan perkembangan teknologi, informasi dan komunikasi setiap peraturan perundangundangan apapun bentuknya jelas merupakan sebuah gagasan, ide yang sudah semestinya merupakan dinamika yang berkembang baik, namun demikian ternyata masih memunculkan beberapa permasalahan-permasalahan umum sebagai bagian dari representasi peradaban budaya bangsa antara lain :

a. Belum terwujudnya transparansi dan keterbukaan, mulai tahap program, perumusan sampai dengan tahap penetapan.

b. Konsensus dan tidak memihak, dengan kata lain dapat menyalurkan kepentingan dan perlakuan secara adil.

c. Efektif dan relevan, dimana memperhatikan dan memfasilitasi kebutuhan-kebutuhan pasar dalam hal ini kebutuhan pemustaka (pengunjung, pemakai) dan pegawai perpustakaan (pustakawan).

d. Dimensi pengembangan, dengan memperhatikan kepentingan public (masyarakat) dan nasional dalam meningkatkan daya saing bangsa.

Permasalahan-permasalahan umum yang mengemuka tersebut, dilingkungan masyarakat pada umumnya dan perpustakaan sendiri mau tidak mau juga muncul permasalahan khusus seperti terbatasnya terbitan/publikasi, perkembangan dan tuntutan teknologi, informasi dan komunikasi.

\footnotetext{
Misi sederhana perpustakaan adalah bagaimana memberikan layanan dan memberdayakan koleksi bahan pustaka, artinya bahwa tatkala sudah ada buku (informasi) carikan

pembacanya, dan tatkala ada pembacanya carikan bukunya (informasinya).
}

Misi ini dapat terselenggara dengan baik tatkala kebiasaan membaca sudah baik, sebaliknya misi ini dapat terwujud dengan baik tatkala terselenggara ketersediaan buku (informasi) yang diperlukan, kenyamanan, kemudahan dan sebagainya.

Dalam Undang-Undang diatur bagaimana koleksi perpustakaan agar lebih berdaya guna dan berhasil guna, Bahwa :

a. Koleksi perpustakaan diseleksi, diolah, disimpan, dilayankan dan dikembangkan sesuai dengan kepentingan pemustaka dengan memperhatikan perkembangan teknologi informasi dan komunikasi.

b. Pengembangan koleksi perpustakaan sebagaimana dimaksud pada no (1) tersebut dilakukan sesuai dengan standar nasional perpustakaan.

c. Bahan perpustakaan yang dilarang berdasarkan peraturan perundangundangan disimpan sebagai koleksi khusus Perpustakaan Nasional.

d. Koleksi khusus sebagaimana dimaksud pada (3) tersebut digunakan secara terbatas.

e. Ketentuan lebih lanjut mengenai penyimpanan koleksi khusus sebagaimana dimaksud pada (3) tersebut dan penggunaan secara terbatas sebagaimana dimaksud pada (4) tersebut diatur dengan Peraturan Pemerintah.

Demikian juga bagaimana pengelola perpustakaan atau pustakawan dapat memperlakukan Layanan Perpustakaan , sebagai berikut :

a. Layanan perpustakaan dilakukan secara prima dan berorientasi bagi kepentingan pemustaka.

b. Setiap perpustakaan menerapkan tata cara layanan perpustakaan berdasarkan Standar Nasional Perpustakaan

c. Setiap perpustakaan mengembangkan layanan perpustakaan sesuai dengan kemajuan teknologi informasi dan komunikasi.

d. Layanan perpustakaan sebagaimana dimaksud pada (a) tersebut dikembangkan melalui pemanfaatan sumber daya perpustakaan untuk memenuhi kebutuhan pemustaka. 
e. Layanan

perpustakaan

diselenggarakan sesuai dengan standar nasional perpustakaan untuk mengoptimalkan pelayanan kepada pemustaka.

f. Layanan perpustakaan terpadu diwujudkan melalui kerjasama antar perpustakaan.

Dalam kerangka pendayagunaan koleksi dan layanan perpustakaan setiap perpustakaan wajib memiliki sarana dan prasarana perpustakaan yang memenuhi persyaratan aspek teknologi, kontribusi, lingkungan, efektifitas, efisiensi dan kecukupan. Khususnya sarana dan prasarana layanan dalam kerangka akses informasi sekurang-kurangnya berupa perabot, peralatan perlengkapan system temu kembali bahan perpustakaan dan informasi. Sarana Teknologi Informasi dan Komunikasi dapat dilengkapi guna pengelolaan koleksi, penyelenggaraan layanan dan pengembangan perpustakaan itu sendiri.

\subsection{Sumber Daya Alat}

Gedung perpustakaan perlu juga dpikirkan tata letak dan design yang representatif serta keamanan dan kenyamanan seperti AC, ada musik (instrumentalia), fotocopy, dan hotspot area sehingga akan menarik pengunjung dan merasa senang di perpustakaan.

Selain gedung/ruangan dan rak buku untuk menyimpan koleksi buku-buku, masih banyak peralatan lainnya yang dibutuhkan. Terutama peralatan untuk membangun perpustakaan digital dan jaringan sistem informasi ilmiah berbasis LAN dan WEB.

\subsection{Sumber Daya Sistem}

Untuk melayani civitas akademika membutuhkan suatu sistem pelayanan yang baik dan akurat. Sistem layanan antara lain struktur organisasi, peraturan-peraturan, prosedur kerja, dan instruksi kerja.

Struktur organisasi dapat berkembang sesuai dengan kebutuhan perpustakaan. Kebutuhan tersebut berorientasi pada kebutuhan pengguna dan perkembangan teknologi informasi.

Penjaminan mutu ISO-9001 sangat berperan dalam meningkatkan kualitas mutu sistem operasional. Peraturan-peraturan, prosedur kerja, dan instruksi kerja utama yang harus ada di perpustakaan antara lain :

a. Peraturan tata tertib yaitu peraturan layanan kepada pengguna perpustakaan (pemustaka) dari mulai masuk perpustakaan sampai penyimpanan barang pengguna perpustakaan.

b. Peraturan perencanaan dan pengembangan bahan pustaka yaitu peraturan untuk mengatur pengadaan dan penyiangan bahan pustaka agar koleksi sesuai prioritas kebutuhan civitas Akademika. Peraturan ini membentuk tim perencanaan dan pengembangan bahan pustaka. Tim terdiri dari pustakawan dan Kaprodi. Tujuannya agar koleksi bahan pustaka di perpustakaan dapat memenuhi sivitas akademika.

c. Prosedur layanan sirkulasi yaitu tata cara untuk peminjaman dan pengembalian buku.

d. Prosedur pengolahan bahan pustaka yaitu tata cara untuk mengolah dan merawat bahan pustaka.

e. Prosedur manajemen keuangan yaitu tata cara pengelolaan keuangan perpustakaan.

f. Prosedur surat menyurat yaitu tata cara pembuatan dan kearsipan surat.

g. Instruksi kerja komputer, instruksi kerja mesin fotokopi, instruksi kerja AC, instruksi kerja mesin scanner dokumen, instruksi kerja mesin genset, instruksi kerja mesin laminating, dan lain sebagainya. Instruksi kerja merupakan tata cara atau prosedur untuk menghidupkan dan mematikan mesin sehingga mesin menjadi tahan lama. Selain itu semua orang bisa melaksanakannya. Misalnya orang yang bertugas menjaga genset tidak masuk maka orang lain bisa menghidupkannya jika listrik padam berdasarkan instruksi kerja yang ditempelkan pada dinding dekat mesin genset tersebut. Jadi tidak harus menunggu orang yang menjaga genset masuk kerja.

Sistem informasi manajemen perpustakaan merupakan pengintegrasian antara bidang pekerjaan administrasi, 
keuangan, pengadaan, inventarisasi, katalogisasi, pengolahan, sirkulasi, statistik, pengolahan anggota perpustakaan, dan lainlain. Tujuannya agar manajemen perpustakaan mudah dilaksanakan dan transparan. Sedangkan sistem informasi ilmiah mencakup tugas akhir mahasiswa, laporan penelitian dosen, hasil pengabdian kepada masyarakat, buku, jurnal dan lain sebagainya. Kedua sistem tersebut berbasis LAN dan WEB.

\subsection{Sumber Daya Lingkungan}

Sumber daya lingkungan merupakan sumber daya yang berkaitan dengan tempat dan masyarakat dilingkungan perpustakaan. Masyarakat yang dimaksud adalah civitas akademika perguruan tinggi. Apakah tempat perpustakaan strategis? Atau apakah budaya baca civitas sudah baik ? Kegiatan-kegiatan untuk membina sumber daya lingkungan merupakan kegiatan

pengabdian kepada masyarakat para pejabat fungsional pustakawan.

Kegiatan-kegiatan untuk membina sumber daya lingkungan, antara lain :

a. Pengenalan perpustakaan pada orientasi mahasiswa baru

b. Pelatihan layanan perpustakaan yaitu mengenalkan tata cara dan instruksi kerja peralatan kepada civitas akademika

c. Pelatihan dan pembinaan layanan perpustakaan terpadu

d. Promosi perpustakaan yaitu mengenalkan koleksi bahan pustaka kepada civitas akademika.

Permasalahan sumber daya lingkungan sebenarnya pada kedekatan antara perpustakan dengan civitas akademika. Ibaratnya perpustakaan menjual jasa informasi ilmiah dan civitas akademika membelinya?. Antara penjual dan pembeli itu dekat apa tidak Untuk mendekatkan dibuatkan jaringan informasi ilmiah yang menghubungkan antara perpustakaan dengan tempat belajar-mengajar civitas akademika.

\section{Pembangunan Sistem Informasi}

Perkembangan teknologi informasi dan perubahan perilaku masyarakat informasi inilah yang membuat perpustakaan perguruan tinggi membangun sistem informasi.
Pembangunan sistem informasi perpustakaan meliputi :

1. Membuat hotspot area di perpustakaan

2. Menyediakan layanan internet untuk pengguna perpustakaan

3. Mengalih mediakan bahan pustaka hardcopy menjadi bahan pustaka softcopy dengan membuatkan bookmark dan watermark pada bahan pustaka softcopy

4. Membuat katalog berbentuk multimedia.

5. Membuat koleksi dalam multi format.

6. Menyediakan komputer untuk pustakawan sebagai sarana untuk bekerja

7. Menyediakan komputer untuk pengguna sebagai sarana untuk mengetik dan mencetak

8. Membuat akses ke sumber informasi di internet yang menyediakan bahan informasi sesuai kebutuhan civitas akademika dan dapat dipercaya.

9. Membuat homepage perpustakaan yang menyajikan informasi bibliografi koleksi bahan pustaka, tugas akhir mahasiswa, laporan penelitian dosen, laporan pengabdian masyarakat dari dosen, pameran online, pendidikan pemakai, berita perpustakaan, informasi lokal, media komunikasi dengan pengguna, hubungan dengan situs lain, dan lain sebagainya. Informasi ilmiah disajikan dalam bentuk full text.

10. Membuat jaringan sistem informasi berbasis LAN dan WEB yang menghubungkan perpustakaan dengan tempat belajar-mengajar civitas akademika. Jaringan tersebut untuk sarana sistem informasi manajemen perpustakaan dan sistem informasi ilmiah

11. Menjalin kerjasama informasi ilmiah dengan perpustakaan lain

12. Membuat perpustakaan digital dengan layanan full text informasi

\section{Evaluasi}

Evaluasi koleksi adalah kegiatan menilai koleksi perpustakaan baik dari segi ketersediaan koleksi itu bagi pemustaka 
maupun pemanfaatan koleksi itu oleh pemustaka. Tujuan dari evaluasi koleksi pada perpustakaan perguruan tinggi menurut dokumen "Pedoman Perpustakaan Perguruan Tinggi " (2005) adalah :

a. Mengetahui mutu, lingkup dan kedalaman koleksi

b. Menyesuaikan koleksi dengan tujuan dan program perguruan tinggi

c. Mengikuti perubahan, perkembangan sosial budaya, ilmu dan teknologi

d. Meningkatkan nilai informasi

e. Mengetahui kekuatan dan kelemahan koleksi.

f. Menyesuaikan kebijakan penyiangan koleksi.

Walaupun tujuan yang disebutkan di atas untuk perpustakaan perguruan tinggi, namun materi tersebut bisa digunakan untuk perpustakaan jenis yang lain.

Ada banyak kriteria untuk penentuan nilai dari sebuah buku atau keseluruhan koleksi, misalnya : secara ekonomi, moral, keagamaan, estetika, intelektual, pendidikan, politis dan sosial.

Nilai sebuah benda atau koleksi berfluktuasi tergantung pada ukuran mana yang digunakan. Mengkombinasikan beberapa ukuran adalah efektif sepanjang ada kesepakatan menyangkut bobot relatifnya.

Banyak faktor-faktor subjektif berlaku dalam proses evaluasi yang harus dilalui sebelum mulai melaksanakan proses tersebut.

Suatu keuntungan bila sudah ditentukan tujuan dan kriteria nilai-nilai sebelumnya, sehingga interpretasi hasil bisa dilakukan dengan lebih mudah. Hal itu juga akan membantu memperkecil perbedaan dalam pemikiran tentang hasil-hasil.

Perpustakaan melakukan evaluasi untuk beberapa alasan :

a. Untuk mengembangkan program pengadaan yang cerdas dan realistis berdasarkan pada data koleksi yang sudah ada.

b. Untuk menjadi bahan pertimbangan pengajuan anggaran untuk pengadaan koleksi berikutnya. c. Untuk menambah pengetahuan staf pengembangan koleksi terhadap keadaan koleksi.

Langkah-langkah berikut ini disarankan untuk diambil dalam mengevaluasi koleksi, meliputi : pengembangan standar nilai dan mutu pengembangan koleksi, mengambil contoh secara acak dari koleksi dan memeriksa pemanfaatan buku itu, mengumpulkan data tentang judul-judul yang diinginkan pemustaka, mengumpulkan data judul-judul yang dibaca ditempat, mengumpulkan data dari aktivitas pinjam antar perpustakaan dan sebagainya.

Melakukan evaluasi koleksi memang menyita banyak waktu, tetapi dari hasil evaluasi ini akan diketahui kekuatan dan kelemahan koleksi. Dengan data itu, maka staf pengembangan koleksi dapat memformulasikan kembali perencanaan untuk terus memelihara koleksi yang kuat dan memperbaiki koleksi yang lemah. Semua aktifitas evaluasi ini tentunya harus sejalan dengan fungsi dan tujuan perpustakaan serta kebutuhan komunitas. Bila evaluasi koleksi ini sudah dilakukan secara rutin, akan terasa semakin ringan tugas ini, terlebih bila diingat bahwa proses ini akan membawa koleksi perpustakaan semakin dekat dengan kebutuhan komunitas yang dilayani.

Evaluasi perlu dilaksanakan untuk mengatasi permasalahan-permasalahan yang timbul dan membuat kualitas layanan menjadi akurat, efektif dan efisien. Evaluasi kegiatan perpustakaan disajikan dalam bentuk laporan tahunan perpustakaan yang berbentuk portofolio. Kegiatan evaluasi lainnya merupakan kegiatan evaluasi berbentuk analisis atau kajian. Contoh-contoh analisis untuk mengevaluasi perpustakaan :

a. Analisis kepuasan pengguna terhadap mutu layanan Perpustakaan

b. Kajian koleksi bahan pustaka terhadap kebutuhan pengguna

c. Analisis kekuatan dan kelemahan Perpustakaan untuk bahan renstra

d. Analisis kepemimpinan Perpustakaan terhadap kepuasan kinerja karyawan

e. Analisis formasi jabatan fungsional pustakawan 
f. Evaluasi perpustakaan digital melalui Transaction Log Analysis (TLA)

Dari analisis tersebut akan diketahui permasalahan -permasalahan di perpustakaan. Permasalahan tersebut selanjutnya ditindaklanjuti untuk diperbaiki.

Kriteria penilaian layanan perpustakaan yang bagus adalah dilihat dari kualitas koleksinya. Koleksi yang dimaksud adalah yang mencakup berbagai format bahan sesuai dengan perkembangan dan kebutuhan alternative para pemustaka perpustakaan terhadap media rekam informasi. Salah satu aspek penting untuk membuat perpustakaan itu banyak digunakan adalah ketersediaan koleksi yang memenuhi kebutuhan penggunanya. Oleh karena itu tugas utama setiap perpustakaan adalah membangun koleksi yang kuat demi kepentingan pemustaka. Pustakawan yang diberi tugas di bidang pengembangan koleksi, harus tahu betul apa tujuan perpustakaan tempat mereka bekerja, siapa penggunanya dan apa kebutuhannya.

Dalam pemanfaatan layanan perpustakaan, para pemustaka tentu memerlukan berbagai fasilitas seperti : katalog atau basis data yang efektif, skema klasifikasi yang mudah dipahami, dan sistem sirkulasi yang efisien. Tapi itu semua hanya merupakan sarana atau media yang membantu para pemustaka agar mudah menemukan informasi yang diperlukannya dari jajaran koleksi perpustakaan. Dimana nantinya para pemustaka akan lebih mementingkan dan mencurahkan perhatiannya pada pengelolaan serta pengamanan koleksi perpustakaan yang menjadi kebutuhan aktualnya.

Koleksi perpustakaan ini dapat dibangun dan dipelihara dengan baik melalui kegiatan pengembangan koleksi yang terencana dan dilakukan secara sistematis. Untuk melihat apakah tujuan perpustakaan sudah tercapai dan bagaimana kualitas koleksi yang telah dikembangkan tersebut sudah memenuhi standar, perlu diadakan suatu analisis dan evaluasi koleksi.
Evaluasi koleksi adalah kegiatan menilai koleksi perpustakaan baik dari ketersediaan koleksi itu bagi pemustaka maupun pemanfaatan koleksi oleh pemustaka.

Pedoman untuk mengevaluasi koleksi perpustakaan yang dikeluarkan oleh American Library Association membagi metode kedalam ukuran - ukuran terpusat pada penggunaan. Dalam setiap kategori ada sejumlah metode evaluasi khusus. Perpustakaan perlu melakukan evaluasi koleksi secara periodik dan sistematik untuk memastikan bahwa koleksi itu mengikuti perubahan yang terjadi, dan perkembangan kebutuhan dari komunitas yang dilayani.

Perpustakaan sebagai unit pemberi jasa/layanan selalu menaruh perhatian pada pengukuran kinerja dalam memenuhi kebutuhan para penggunanya, dan meyakinkan diri bahwa berbagai sumber daya yang dipilih bermanfaat bagi konsumennya. Akhir-akhir ini minat untuk pengukuran kinerja semakin menguat. Hal itu sebagian disebabkan oleh tekanan untuk lebih memanfaatkan sumber daya dengan lebih efisien, bersamaan dengan oleh tekanan untuk lebih memanfaatkan sumber daya dengan lebih efisien, bersamaan dengan perhatian pada pemenuhan kebutuhan pemustaka dengan lebih efektif. Disamping itu juga adanya tekanan dari pihak penyandang dana untuk memanfaatkan dana secara optimum, pada waktu yang sama pemustaka dari jasa-jasa perpustakaan semakin tinggi tuntutannya. Setiap penilaian pada koleksi seharusnya memasukkan sebuah pertimbangan pada seberapa baiknya koleksi itu memenuhi harapan dan kebutuhan pemustaka.

Demikian luasnya fungsi perpustakaan bagi para pemustaka (civitas akademika), pada kenyataannya tugas dan fungsi tersebut di atas belum dapat dilakukan dengan optimal oleh pihak perpustakaan. Hal ini dikarenakan berbagai kendala yang terkadang sulit dipecahkan misalnya dalam pemenuhan kebutuhan sumberdaya manusia dan sarana dalam pelaksanaan tugas. Adanya aturan aturan panjang dalam rangka pengadaan sumber daya manusia atau peralatan perpustakaan. 
Selain itu perbandingan antara pemustaka yang dilayani dengan petugas yang ada belum sesuai. Petugas dengan kualifikasi pendidikan selain ilmu perpustakaan, kadang kurang pas ditempatkan di perpustakaan. Akibatnya, peranan sebagai pelayan perpustakaan dijalankan dengan setengah hati, karena kurangnya penghayatan/pemahaman tentang perpustakaan. Akhirnya pelayanan yang diberikan kurang ikhlas/sabar. Padahal peran petugas (pustakawan) sangatlah menentukan berfungsi tidaknya sebuah perpustakaan.

Apabila pemustaka mau menggunakan perpustakaan lebih dari sekali, maka dapat diartikan bahwa perpustakaan berfungsi dalam menjalankan tugasnya, dan pemustaka paham peran perpustakaan untuk kepentingannya.

Perpustakaan perguruan tinggi juga sering disebut sebagai perpustakaan khusus. Hal ini dikarenakan perpustakaan perguruan tinggi pada umumnya khusus melayani civitas akademikanya. Disamping itu, koleksi yang dimiliki perpustakaan perguruan tinggi pun khusus untuk mahasiswa maupun dosen. Bila dibandingkan dengan perpustakaan umum, maka perpustakaan perguruan tinggi memiliki kelebihan, yaitu berupa koleksi hasil-hasil para civitas akademikanya.

\section{SIMPULAN}

Dari pemaparan dapat disimpulkan bahwa pola pengembangan perpustakaan perguruan tinggi merupakan pembangunan pondasi dasar perpustakaan yang kuat dan disertai dengan pembangunan sistem informasi yang canggih dan berorientasi pada kebutuhan civitas akademika. Kebutuhan kualitas sumber daya manusia yang handal sangat diperlukan untuk mengelola perpustakaan sehingga dapat menuju perpustakaan bertaraf internasional.

Setiap pengunjung perpustakaan merupakan penikmat perpustakaan, dan secara tidak langsung mengetahui kegunaan perpustakaan. Sesudah melakukan kegiatan di suatu perpustakaan, pengunjung mendapatkan sesuatu yang langsung dirasakan maupun secara tidak langsung bermanfaat untuk dirinya. Adapun kenikmatan akan ditularkan kepada orang lain atau dinikmati sendiri tergantung kepada pribadi seseorang.

Berlangsungnya kegiatan di sebuah perpustakaan sangat tergantung dari berbagai unsur yang saling berkaitan sehingga bermanfaat untuk banyak fihak. Koleksi, tenaga, tempat, sistem dan peralatan bersatu dalam kesepakatan untuk menyajikan informasi sesuai permintaan dengan optimal.

Sedangkan untuk keberlanjutan
pengembangan perpustakaan dengan
melakukan perbaikan-perbaikan maupun
perawatan-perawatan baik itu operasional di
perpustakaan maupun di jaringan LAN dan
WEB. Inovasi dan kreatifitas dibutuhkan untuk
membuat suatu ide-ide baru yang efektif dan
efisien dengan mengikuti perkembangan
teknologi informasi.

\section{DAFTAR PUSTAKA}

Departemen Pendidikan Nasional : Direktorat Jenderal Pendidikan Tinggi, 1994, Buku Pedoman Perpustakaan Peguruan Tinggi Edisi Kedua, Jakarta

Departemen Pendidikan Nasional : Direktorat Jenderal Pendidikan Tinggi, 2004, Buku Pedoman Perpustakaan Peguruan Tinggi Edisi Ketiga, Jakarta

SNI 7330:2009. Standar Nasional Indonesia Perpustakaan Perguruan Tinggi. Jakarta. 2009 